\title{
EXPLORING THE INTEGRATION- INTERCONNECTION PARADIGM IN THE INDONESIAN CONTEXT OF COMMUNITY EDUCATION AND PRACTICE
}

\author{
Muchammadun \\ Universitas Islam Negeri (UIN) Mataram \\ Email: muchammadun@uinmataram.ac.id
}

\begin{abstract}
The paper explores the daunting question as to how the integration-interconnection paradigm is actualised in the context of academic disciplines in Indonesia. This is accomplished by specifically analysing its application, through a purposive sampling of previously published studies, to the field of community development. The subsequent conclusions reveal core features of the integration-interconnection paradigm and its historical roots, and their relevance for community education and development today. In supporting the integration-interconnection paradigm, the writer proposes that Rothman's and Ann Jeffries' revised community development model is suitable for modification to accommodate local community education and practice in Indonesia. The paper identifies three major findings from studies in this field and discusses their implications. Firstly, from the epistemological point of view, there is a growing belief that science and religion are able to engage in collaborative dialogue rather than exist in mutual isolation. This will ensure an enhanced understanding of human interaction within our social environment. Secondly, religion and spirituality may potentially contribute to establishing a shared-base for supporting ethical values for professional practice. The final finding is that community developers, working from these underpinning assumptions, are more likely to succeed in their goals through exploring participatory ways of community practice.
\end{abstract}

Keywords: Integration-Interconnection Paradigm, cross cultural diversity, community education, development models

DOI: https://doi.org/10.20414/ujis.v24i1.377 


\section{Introduction}

EPISTEMOLOGY has long been structured chiefly on western concepts. However, there are a range of alternate practices for knowledge creation and social wellbeing in cultures existing in other parts of the world. While an increasing awareness of crossreligious and cultural diversity is emerging in this era of widespread social disruption, the challenge is continuing as to how Islamic knowledge and education can construct a model of integration- interconnection of religion and science.

In the discipline of community education and development, a number of scholars, such as Ragab ${ }^{1}$ and Soeharto ${ }^{2}$, argue that often the models of community development ${ }^{3}$ in developing countries are not critically assessed enough before adopting concepts originally developed in the West. This is the situation currently occurring in Indonesia where there is a need to explore a model of community development that accommodates value of local cultures. Recent scholarly research argues that the paradigm of integration-interconnection may provide a philosophical bridge to accommodate this need. However, this paradigm needs to be consolidated at theoretical level, as an academic discipline, and in practical level.

This paper seeks to shed light on these issues through analyzing the integration-interconnection philosophical model, both as an academic discipline and in the practice of community education and development. The analysis is framed within three sections. The integration-interconnection paradigm is dissected to see what elements best accommodate each field locality. A

${ }^{1}$ Ibrahim A. Ragab, "How Community Development Can Take Root in Developing Countries", Journal of Social Development Issues 12, no. 3 (1990): 38-51.

2 Edi Soeharto, Pembangunan Sosial dan Pengembangan Masyarakat, Spektrum Pemikiran (Bandung: LSP-STKS, 1997), 350-352.

3 Definition by the International Federation of Social Work at the International Conference in Montreal, Canada: July 2000 in Ngoh Tiong Tan and Ellis Enval, "Social Work: Challenges in the New Millenium", in Social Work around the World, ed. Ngoh Tiong Tan and Ellis Enval (Zurich: IFSW Press, 2000). IFSW explains social work as a profession contributing to the problem solving of human relation, social changes, empowerment and human liberation as well as community well-being. 
discussion on the distinctive models of the paradigm, through comparison with the Islamization of science, is subsequently included to clarify the differences between the two. Finally, the application of the paradigm at a practical level is outlined through proposing an interconnected model of community development.

\section{Wholeness and Interface Features}

Kuhn defines paradigm as the legitimate problems and methods of a research field for succeeding generations of practitioners. ${ }^{4}$ Nevertheless, any specific viewpoint assumed by the researcher inevitably creates a consequence impacting on the construction of reality. ${ }^{5}$ Existing evidence, however, suggests that the paradigm of integration-interconnection creates no dichotomy between religion and science. Instead, religion and science have the potential to engage a wide range of temporal knowledge systems in order to contribute to improved community wellbeing, such as the provision of social welfare services. The integrationinterconnection paradigm features elements of wholeness and integration while it also recognizes other sources of knowledge, such as the Divine. It permits practitioners to explore ways of negotiating the complexities of contemporary social problems through interfacing and interconnecting with other disciplines, thus effectively contributing to better social functioning. The integration-interconnection model enables community developers to establish a community development model that caters for each unique local setting.

The rationale for the integration-interconnection paradigm can be best appreciated through examining the history of knowledge

${ }^{4}$ Thomas Kuhn, The Structure of Scientific Revolutions (Chicago: University of Chicago Press, 1970), 15. The view of Islamic studies is of a paradigm shifting: a process of re-conceptualizing about some model, pattern, or perception, leading to significant changes, or "reinventions", such as described in L. R. Barker, The Social Work Dictionary (Washington DC: NASW Press, 2003), 312.

${ }^{5}$ A number of other social science researchers such as P. Robbin, Pranab Chatterjee, Edward R. Canda believes that a certain ideology drives a certain action, refer to "Ideology, Scientific Theory, and Social Work Practice", Journal Families in Society 80, no. 4 (384 374AD): 374-384. and also John H. Coates, "Ideology and Education for Social Work Practice", Journal of Progressive Human Services 2, no. 3 (1992): 15-30. 
transformation in the humanities and social sciences. The evidence from historical records testifies that both Islam and Christianity referenced the same earlier Graeco-Roman philosophical tenants for their epistemology. ${ }^{6}$ It is apparent that Islamic knowledge interconnected with other non-Islamic knowledge systems from early times. The following discussion of Graeco-Roman philosophy selects those aspects that form the ancestry to modern day social welfare practices. ${ }^{7}$ It suggests a bridge between the general guidance of Qur'an and hadith, and the many dislocated elements found in various modern-day approaches and techniques that seek to transfer knowledge into skilled practice. ${ }^{8}$

\section{From Plato through al-Kindi to Ibn Sina}

The earliest basic concept of community development can be traced back to 378 years before the Christian era. This is the notion of an ideal society that was expounded by the Greek philosopher

6 The Islamic and Christian civilizations derived from the same GraecoRoman source. Both civilizations developed their sciences on the basis of knowledge expounded by this earlier civilization. The introductory chapters from Richard W. Bulliet and Charles Homes Haskin highlight the philosophical similarity of Islam and Christianity civilizations as well as their cultural interconnectedness. For further details refer to Richard W. Bulliet, The Case for Islamo-Christian Civilization (New York: Columbia University Press, 2004). For example, Chapter I explains that the Islamic civilizations list music, literature and gun powder as having been adopted from the Christian civilization during the interbellum peace of the medieval Crusader Wars. In The Rise of the Universities, Haskins reports his research findings that universities, in terms of finely organized instruments such as faculties, subjects, examinations and scheduling as well as the degree awarding commenced in the Mediaeval period. The universities of Bologna and Paris have been prominent initiators for the establishment of this institution, inspired by the historical roots of Graeco-Roman academic tradition. The Western world, however, also recognizes its indebtedness to Islamic civilization for preserving Graeco-Roman knowledge during the time of Europe's economic and political upheavals known as the Dark Ages. See Charles Homer Haskins, The Rise of Universities (New York: Cornel University Press, 1965), 1-3.

${ }^{7}$ Barker, The Social Work Dictionary, 238, states 'The knowledge base... is derived from research, theory building, and systematic study of relevant phenomena and from direct and reported experiences of others.'

${ }^{8} \mathrm{~A}$ pertinent adagium for this is 'standing on the shoulder of a giant' in order to transform ideology into practical methods. 
Plato in his text The Republic. During the 27 year long war between the city-states of Athens and Sparta, Plato considered the idea as to whether an ideal community could exist and how it could best function. A fundamental question in his thought concerned the impact arising from the conflict of interests between contesting parties and how these conflicts had weaken the foundations of civilization. From a reductionist perspective, Plato believed that a political state needed to be organized in a somewhat similar way to how a person ought take care of his/her own health. Such an analogy became the philosophical basis of a biological model for the professional health-care disciplines, such as Nursing Science, Social Work and Psychology. ${ }^{9}$

Plato's theories align with the thoughts of early Islamic philosophers. Al-Kindi (d.873 CE), for example, also argues that there should be a similarity that is able to unify social differences. Al-Kindi, a prolific Muslim author, was among the first few writers who were fully aware of the significance of the heritage of Graeco-Roman wisdom for Muslims. His work On First Philosophy clearly conveys the proposition that we need to first identify similarities in order to recognize difference:

We ought not to be ashamed of appreciating the truth and of acquiring it whenever it comes from. ${ }^{10}$

The prominent philosopher argued people ought to be eager to learn new ideas, even if they came from distance races or nations. Relocated to a contemporary context, his argument includes learning from people of different social stratifications, religions and cultures. ${ }^{11}$

${ }^{9}$ Stroll and Popkin, in Frederic G Reamer, The Philosophical Foundations of Social Work (New York: Columbia University Press, 1993), 4.

10 Al-Kindi. Al-Kindi's Metaphysics: Al-Kindi's Metaphysics; a Translation of Ya'qub ibn Ishaq al-Kindi's Treatise On First Philosophy, trans. A. L. Ivry (Albany: State University of New York Press, 1974), 58.

11 The thoughts of al-Kindi can be summarized as following: The central concept in the theology of On First Philosophy, however, is neither truth nor being, but oneness. Indeed al-Kindi argues for a first cause of being precisely by arguing for a first cause of oneness, and asserting that "bringing something to be" means imposing unity of a certain kind. Al-Kindi's philosophical theology thus has two main aspects: a proof that there must be some "true One" that is the cause of the unity in all things, and a discussion of the nature of this true One. These aspects 
Another Muslim scholar, Ibn Sina (980-1037 CE) further developed al-Kindi's proposition. According to Ibn Sina, ${ }^{12}$ mental thoughts are emergent from interactive sensations. These thoughts sub-sequently trigger the way humans refer to universal nature, a philosophical term that is defined as an 'authentic understanding of the inner structure of the world.' ${ }^{13}$ The universal nature is potentially pre-existent but requires an external trigger to come into being. This implies that knowledge of physical and mental wellbeing comes not only from the purification of the body through ritual prayers but also from positive social interactions through exchanging ideas and mutual co-operation under the principles of equality and equity. ${ }^{14}$

Understanding idea exchange and mutual cooperatiocan best be exemplified by the history of the development of medical

are treated, respectively, in the third and fourth sections of On First Philosophy. See Stanford University, http://plato.stanford.edu/entries/al-kindi/, accessed April 21, 2013.

12 Avicenna (Ibn Sīnā), "Ibn Sīnā" Al-Najah (Cairo, Egypt, 1923), Arab Republic of Egypt, National Commission for UNESCO, Islamic and Arab Contribution to the European Renaissance (Cairo, Egypt: Associated Institution for the Study and Presentation of Arab Cultural Values, General Egyptian Book Organization, 1977).

${ }^{13}$ Stanford Encyclopedia of Philosophy describes universal nature as 'authentic understanding of the inner structure of the world'. Refer to "Ibn Sina's Metaphysics", Stanford Encylopedia of Philosophy (Standford, n.d.), accessed December 20, 2019, http://plato.stanford.edu/entries/ibn-sina-metaphysics/. For Ibn Sina, science is a perfectly established rationale for human thinking in which the systems come from the fusion of Aristotelian tradition but are renewed to recognize Theology, Cosmology and Angelology as the base of universal base system of all knowledge. See J. A. Aertsen, "Avicenna's Doctrine of the Primary Notions and Its Impact on Medieval Philosophy", in Islamic Thought in the Middle Ages: Studies in Text, Transmission and Translation, in Honour of Hans Daiber, ed. A. Akasoy and W. Raven (Leiden, Boston: Brill, 2008), 21-42; P. Adamson, Interpreting Avicienna: Critical Essays (Cambridge: Cambridge University Press, 2013).

${ }^{14}$ L.R. Barker, The Social Work Dictionary (Washington DC: NASW Press, 2003), 146 argues that equality is: the principle that individuals should have equal access to services, resources, and opportunities and be treated the same by all social, educational, and welfare institutions; where fundamental community wellbeing value must be in a right balance with equity: the state of fairness or impartiality, including any systems (for example the criminal justice system and social welfare system) that determine how one's rights and claims are fulfilled. 
science in the Islamic world. Theories of medical science in the pre-modern Islamic times generally were based on the work of the Greek physician Galen (130-210 CE). Muslim physicians subsequently translated and systematized his thoughts. Furthermore, their critical approach developed Galen's ideas into the creation of a flexible scientific system covering all known streams of medicine. Thus we see the key to advancement is recognizing the work of others, learning from pre-existing knowledge systems and then challenging and expanding those ideas through new innovations. ${ }^{15}$

This kind of open-mindedness and willingness to exchange ideas form an essential educational value for a community who holds to religion. The interconnectedness of religion and philosophy, as exemplified by Saparudin ${ }^{16}$ and Ahmad $^{17}$ is a relevant issue for community development because it requires appropriate education methods, encompassing curriculum (both written and hidden) and syllabus planning. ${ }^{18}$ This also includes teaching and learning processes that support the three following principles of community development practice. ${ }^{19}$

15 Michael Frassetto, Christian and Muslims in the Middle Ages From Muhammad to Dante (New York: Lexington Books, 2020), 55; Andreas Lammer, The Elements of Avicenna's Physics: Greek Sources and Arabic Innovations (Berlin: Walter de Gruyster GmbH, 2018).

16 Saparudin Saparudin, "Salafism, State Recognition and Local Tension: New Trends in Islamic Education in Lombok," Ulumuna 21, no. 1 (June 30, 2017): 81-107, accessed June 10, 2020, https://ulumuna.or.id/index.php/ ujis/article/view/68.

17 Nur Ahmad, "Shedding New Lights on Javanese Mysticism: Pegon Manuscripts in the Javanese World," Ulumuna 23, no. 2 (2019): 221-241, accessed June 10, 2020, https://ulumuna.or.id/index.php/ujis/article/view/370.

${ }^{18}$ Curriculum refers to subjects while a syllabus analyses a curriculum into its components and the steps of instruction, teaching and learning activities in which students engage. A hidden curriculum is defined as the implied ideologies, perspectives, values, behavior and customs not formally articulated in a curriculum document but which students absorb in their day-to-day school experiences. See research into education sociology interests such as documented in Merfat Ayesh Alsubaie, "Journal of Education and Practice", Journal of Education and Practice 6, no. 33 (2005), www.iiste.org.

${ }_{19}$ M. Amin Abdullah, "Implementasi Pendekatan Integratif-Interkonektif dalam Kajian Pemikiran Pendidikan Islam Fresh Ijtihad memperjumpakan Ulum al-din dan sains modern dalam pemikiran Pendidikan Islam" in M. Amin 
The first principle is the sum of the whole is greater than its parts. Professional practice in community development ought to include the 'complete package' of knowledge, skills and ethics. It implies that hadarah al-nas (religious texts) can never stand-alone but requires to be integrally interconnected with hadarah al-'ilm (subject matter) and hadarah al-falsafah (philosophy and ethics). Religion, seen from this perspective, can become an ethical basis for professional practice.

The second principle is that there needs to be the common viewpoint among community developers regarding hadarah alfalsafah (ethics) as a support for empirical knowledge (hadarah al'Ilm). This shared perspective recognizes social wellbeing can best be achieved by having a thorough understanding of the components that constitute the environmental context in which each person lives. This requirement counter balances the act of merely focusing on religious textual interpretation. It promotes Quranic exegesis and nurtures critical discussion through contextualizing doctrinaire religious rituals within a transformative social praxis.

The third and final principle of community development practice acknowledges that ethics in hadarah al-falsafah (transformative, liberative and humanistic in nature) will always be a key point of reference whenever a problem arises from hadarah al-ilm.

The total interconnectedness of the three principles can therefore be illustrated in the following diagram:

(Religion):

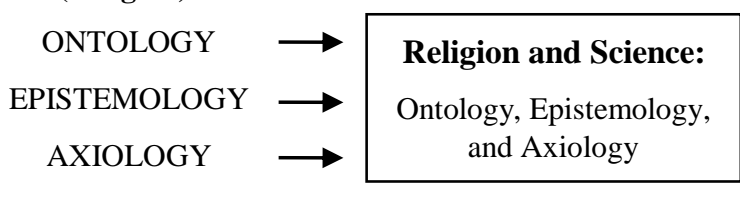

(Science):

ONTOLOGY

EPISTEMOLOGY

AXIOLOGY

Figure 1. The Integration and Interconnectedness of Religion and Science

Abdullah et.al, Implementasi Pendekatan Integratif-Interkonektif dalam Kajian Pendidikan Islam (Yogyakarta: Program Pascasarjana UIN Yogyakarta, 2014), 1-32. 
In terms of accommodating the notion of locality, the question arises whether the knowledge and practice of community development ought to be based on notions of religious authenticity or modes of indigenization. The following section examines the underlying assumptions surrounding this issue.

\section{Authenticity versus Indigenization}

In the Indonesian context, there are two different concepts regarding community education development: authenticity and indigenization. The opposite terms ought to be clearly examined on the basis of their philosophical roots: Islamization of science versus integration-interconnection model. Despite common assumptions that they are compatible, the Islamization of science and integration-interconnection are two different paradigms of epistemology.

The view of the Islamization of science depends on the proposition answering a number of challenges within the framework of Islamic knowledge and practice with its distinctive authenticity. Authenticity refers to:

... [the] identification of genuine and authentic roots in the local system, which would be used for guiding its future development in a mature, relevant and original fashion. ${ }^{20}$

The word 'genuine' derives from the Latin root genuinus meaning 'truly what is something is said to be, real' and 'authentic' is from the Latin authenticus meaning 'of an undisputed origin'. The two adjectives are interconnected and it is almost impossible to identify a difference between the two in modern usage. Both terms applied to the Islamisation of science imply that scientific creativity in a Muslim context needs be distinctively Islamic in its true origins.

A number of community practitioners argue that authentication is the right model for community education and practice in a cross-cultural setting. For example, Gray dan Fook propose that the adoption of the Western concept in the context of

${ }^{20}$ Ibrahim A. Ragab, Authentization of Social Work in Developing Countries (Tanta, Egypt: Integrated Social Services Project Publication, 1982), 21. 
local community practice will bring operative problems. Thus they reflect the need for:

...contemporary efforts to deal better with diversity-being mindful of cultural sensitivity, competence, appropriateness, and relevance. ${ }^{21}$

Ragab, an Egyptian community developer, is convinced that the socio-economic problems in developing countries will never be able to be solved from the Western perspective of development. ${ }^{22}$ He proposes a model of community development authentication defined as:

a process through which the profession becomes true to the nation's identity, its defining characteristics, and its cultural and social realities. ${ }^{23}$

The key point established by his definition is that community development authentication starts from the initial process and culminates in establishing an identity whose characteristics fit with the local socio-culture environment. On the other hand, the paradigm of integration-interconnection does not focus on claiming science to be Islamic. Instead it brings the philosophical recognition that religion and science are mutually cooperative. Religion needs to interconnect with other disciplines in order to enhance positive social functioning. ${ }^{24}$ This implies support for the adaptation of thoughts and ideas from other religions and

${ }^{21}$ Mel Gray, John H. Coates, and Michael Yellow Bird, Indigenous Social Work Around the World: Towards Culturally Relevant Education and Practice (Burlington: Ashgate Publishing Company, 2010).

22 Ibrahim A. Ragab, “The Islamic Perspective on Social Work: A Conceptual Framework", Journal International Social Work 59, no. 3 (2016): 325-342.

${ }^{23}$ Ibid., 327.

${ }^{24}$ M. Amin Abdullah, "Epistemologi Ilmu Profetik: Apa yang Terlupakan dari Ilmu-ilmu 'Sekuler'?" (Paper presented at the Sarasehan Ilmu Profetik II, Ruang Sidang A Lt. 5 school of Post Graduate studies, UGM, July 28, 2011), 1-2. Further description could also be found in his other work such as "Interpreting the Quran Responding to the Challenges of the Modern World: Moslem Societies at Crossroads" (Paper presented at the Symposium on Social, Ethical, and Policy Implications of Interpretations of Islam's Foundational Text: The Quran, New York University's Casa Italiana, November 28, 2010), 26. And also "Religion Science and Culture an Integrated, Interconnected Paradigm of Science", AlJami'ah: Journal of Islamic Studies 52, no. 1 (2014): 175-203. 
cultures, as exemplified by Chotimah Bimbo $^{25}$ in the case of Islam in the modern West.

With this understanding, some community developers introduce an adaptive approach to their practice. Bullis ${ }^{26}$, for example, has formulated a Western community work concept that synthesizes with local practices through a cross-cultural approach. This implies the skill-set of community developers ought to be complemented by ethical open mindedness to diversity and equality through recognizing their benefits to stakeholders. This resonates with what community developers believe. Humanity and its wellbeing are always interconnected with the surroundings. The subsequent positive outcome is that social systems function according to the needs of their environment.

The ideological debate between Islamization of science and integration-interconnection at the philosophical level will certainly bring consequences to the ways systems of community development knowledge and practice are employed. At the methodological level, the debate will determine if the model used for the practice remains authentic to its roots or adapted to fit the local situations. The rationale of this debate is driven by the question, "What sort of cross-cultural awareness and effective interaction model may better achieve locally driven community development?" 27

When community developers, as well as the beneficiaries, can develop open-mindedness, recognize differences and facilitate best practice, the integration of values, local resources and traditions with religion can become an effective community model. An example at the individual or family (micro) level is the process of accepting destiny when a loved one recites the Holy Book in the

25 Chusnul Chotimah Bimbo, "Islam Today in Modern West: Fazlur Rahman's and Tariq Ramadan's Views on Jihad," Ulumuna 23, no. 1 (June 28, 2019): 71-89, accessed June 10, 2020, https://ulumuna.or.id/index.php/ ujis/article/view/289.

26 Ronald K. Bullis, Spirituality in Social Work Practice (Washington DC: Taylor \& Francis, 2005).

${ }^{27}$ A well-noted example is the variety of spirituality practices at the practice of community development such as the practice of Balian healing in Sasak community, Lombok. 
presence of a terminally ill relative. The need for acts of psychological therapy at that moment, both for the terminally-ill patient and for the family, has been widely documented in Western social work studies. However the way this act has become adopted to the local Indonesian context reveals its potential for contributing to social wellbeing at a local level.

Hence it is necessary for community developers to always observe what component resources are locally available and can be best utilized to support the improvement of individual and community wellbeing. As a general guideline, the list of components influencing community's wellbeing could be diagrammatically described by the following illustration:

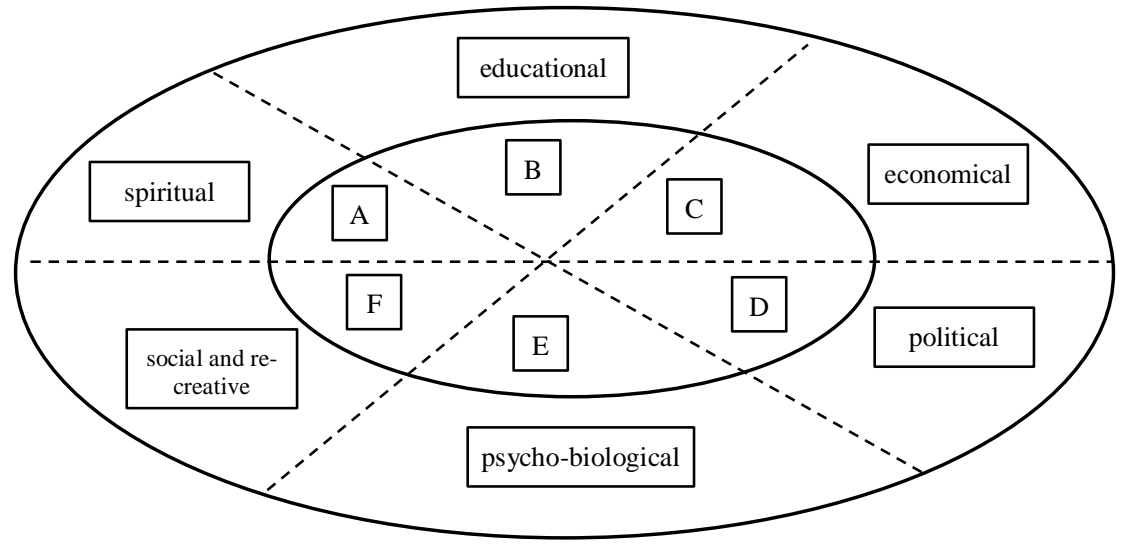

Figure 2. Components Contributing to Human Well-Being

In the Indonesian setting, community development science and practice has reflected the indigenization of Western community development principles rather than being a fully authentic body of knowledge and practice in itself. For example, in the context of democracy and human rights, it is a practice in social planning to conduct musyawarah perencanaan tingkat desal musrenbangdes (collective deliberation) for a village level development plan). In line with this, there are also other ways for the successful interconnection of local wisdom, such as the sharing of community plans at an informal gathering after the morning's prayer in the village mosque. The informal planning gathering at the musrenbangdes is a fine example of how the locality 
development model is facilitated. However, in a situation where the medium of social planning is not yet supported by a local community development framework, social engagement is required to increase community education.

\section{The Interconnection of Education and Community Development}

In a social transformation process, community development commences when behavior changes. The phrase 'behavioral changes' itself is a keyword definition for learning, both in formal school education and community-based education. There is a substantial connection between education and community development. Behavioral change processes that are driven by education lead to social transformation. Gagne ${ }^{28}$, for example, has defined any aspect of behavioral changes as the learning definition. Likewise, Frier ${ }^{29}$ encourages marginalized people to 'name their world' by achieving improvements and engaging actively in efforts to change and transform the community. Such a spirit has inspired participatory approaches at the three levels of community development, social development and citizen participation. Community development, in its wider perspective, addresses interpersonal communication, leadership issues, relation of power and authority as well as overall social transformation. ${ }^{30}$

In relation to behavioral changes, the Indonesian National Development Body (Bappenas) has argued that a community's social behavior also correlates to the level of human development index. ${ }^{31}$ Bappenas has consequently recommended the Ministry of

28 Robert M. Gagne, ed., Learning and Individual Differences (New York: Charles E. Merril Books, 1967), 5.

${ }^{29}$ Paulo Freire, Education for Critical Consciousness (New York: Seabury, 1973), 76-77.

${ }^{30}$ Community development is about working together with a community to empower them to define and solve their problems and being open to express their needs/aspirations in the process of decision making. (Standing Conference for Community Development, 2001).

${ }^{31}$ Using the logarithm factor, Human Development Index (HDI) is measured from three indicators: life expectancy, education, and income per capita. However, further debate arises from what makes the difference in human development outcomes from some countries with the same income per capita. Nowadays, some people and human capability based criteria, such as happiness 
Social Affairs to launch the program known as Conditional Cash Transfer (PKH, Program Keluarga Harapan). ${ }^{32}$ Despite designed by development experts, the program is intended to provide leverage for improving the economy of the beneficiaries. This is achieved through ensuring parents can afford their children's school needs. It also supports building positive parental capacity to transform otherwise counterproductive perceptions and behavior patterns.

However, the sustainability and success of the program also depends on the internal motivation of the community developers and their beneficiaries. There are challenges for PKH despite the affirmative nature of this social action program. These challenges lie in how community developers can act as good role models and facilitators. These skills are necessary for supporting parent beneficiaries to adjust their perceptions and behaviors in order to better develop financial resources. A positive rapport between the funding providers and beneficiaries remains the key to the success of the program. When a community developer successfully embeds awareness regarding the development of financial resources, parents start to set aside some savings from their earnings. This inspires the establishment of small-scale rural livelihood projects, such as breeding goats. Seeing such positive changes in local perceptions, the community developers will in turn be further motivated to seek to replicate this positive practice among other beneficiaries. This is the point where social transformation occurs.

\section{The Model Application in a Local Setting}

The choice of a community development model in the Indonesian context, through considering local community character and cultural values, increases its potential to succeed..$^{33}$

levels, are added up to answer the question. Refer to development websites such as BPS.IPM, "Indeks Pembangunan Manusia", Badan Pusat Statistik, accessed May 7, 2019, https://www.bps.go.id/subject/26/indeks-pembangunan-manusia.html.

32 Indonesia's Program Keluarga Harapan (PKH) is a conditional cash transfer programme for the poorest households eligible for certain requirements. The eligibility include school education for children, attending pre- and post natal check-ups, and completing vaccination for children.

${ }^{33}$ Gray, Coates, and Bird, Indigenous Social Work, 2010. 
The community organization and community development are two of practical methods for approaching community education and practice. They aim to improve the quality of community wellbeing through the optimum utilization of available resources and emphasise the principles of social participation. As a methodology, community organization and community development refer to active interaction where the process of planning, execution, monitoring and evaluation are conducted for a range of social welfare programmes. It is a good practice, however, to consider the emic perspective of the participating beneficiaries and local community developers as well as their implementing agents. This is because the working system depends on this perspective. Such awareness has been well understood in the field of Indonesian social work, where many ethnic groups are culturally diverse.

Furthermore, interconnectivity also harmonizes with social culture in the Indonesian context. Mutual help(tolong-menolong or gotong-royong) have traditionally been regarded as social capital that embodies a core character of Indonesians. These qualities ought not to be distorted by those political groups seeking to raise issues of religion for the sake of vested interests. Visualized diagrammatically, the following model illustrates how models of community development are interconnected.

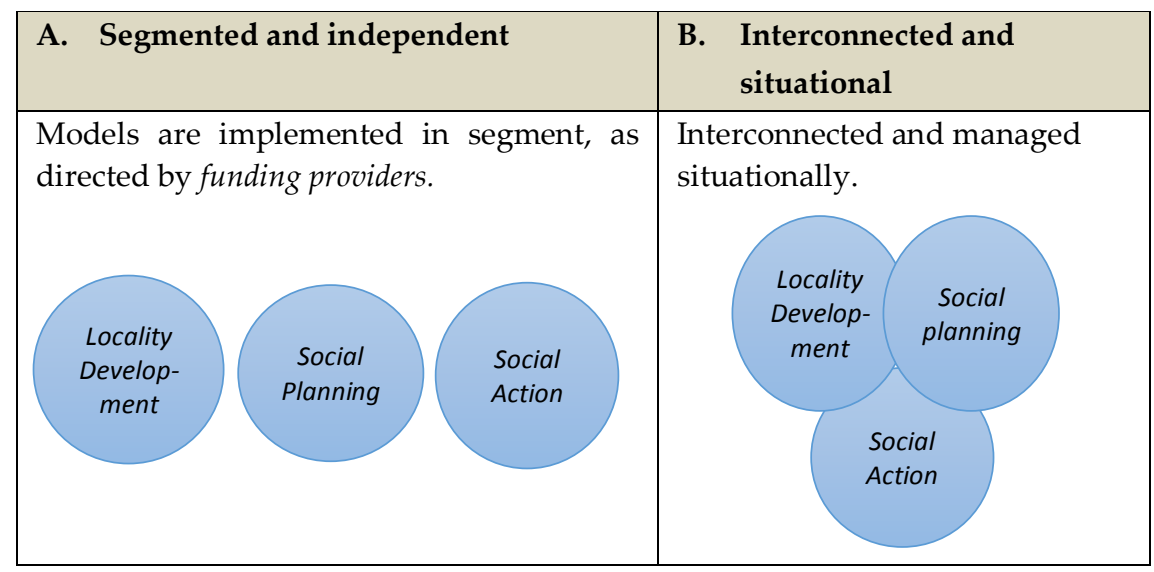

Figure 3. The Transformation of Community Development Models ${ }^{34}$

34 Source: the researcher's synthesis 
Weil and Gamble ${ }^{35}$ support the idea of this interplay between the three models of community development in their observation:

...the current realities of practice reveal a complex and interconnected set of models for community practice".

It is due to the complexity of social problems and diversity of cultures that the interplay between the three models becomes elaborative and inclusive. Their characters can be illustrated in detail in the following diagram. The variables in the diagram represent in what situations a model can be chosen as a commencement point and when they can be re-modelled and interplayed according to the suitability of the changing situation.

\section{Locality Development}

Key words: self-worth and independence

Techniques: awareness and capacity building

\section{Integrated and Interconnected}

Islamic Values: awareness of human

status and willingness to have a go,

such as in: Q.s. al-Ḥashr [59]: 7, al-

Nisā' [4]: 135, al-Inshirah [94]: 7.

\section{Social Planning}

Key words: experts' judgment

Techniques: promotive cooperation

Integrated and Interconnected

Islamic Values: collaborative

techniques such as mushawarah, tolerance, home visits, and halālbihalāl such as in: Q.s. Āli ‘Imrān [3]: 104, 159, al-Nisā' [4]: 86.
Non Violence Campaigns

\section{Social Action}

Key words: access to equality, equity and protection

Techniques: advocacy

Integrated and Interconnected

Islamic Values: advocative communication principles such as karim, ma'ruf, Layyin, dan tsaqila in: Q.s. al-Nisā' [4]: 9, al-Aḥzāb [33]: 70, al-Isrā' [17]: 23 \& 28, al-Nisā' [4]: 5 \& 8, al-Aḥzāb [33]: 32
Key words: resource sustainability

Techniques: capital gain and social reproduction

\section{Integrated and Interconnected} Islamic Values: zakat, infaq, and sodaqoh as well as establishing business unit to sustain the fund, such as in: QS at-Tawbah [9]: 11, 60, al-Hadīd [57]: 10-11, Shaff [61]: 10.

Figure 4. The Proposed Model of Community Development Indigenization

35 Mary O. Weil and Dorothy N. Gamble, Community Practice Models in Encyclopedia of Social Work (Washington: NASW Press, 1995), 580. 
The model consisting of four interconnected quadrants is not meant to represent the Islamization of science but the foundation for ethics and knowledge, derived from religion, as it appears analyzed into operational steps.

\section{Conclusion}

This paper examines the significance of the integrationinterconnection model for Indonesian community development while acknowledging the role of religion, in the context of Islam, as a driving force for social transformation. Religion can bring positive influences on community development under the condition that religious teachings are practised with critical thinking and open mindedness towards social diversity. At the level of community practice, religion can be the foundation of ethics, thus realising a distinctive ethical practice at the individual level. Prayer rituals therefore need to be consistently maintained as part of social practices because the contribution of religion supports the attainment of social welfare.

In conclusion, it is pertinent to observe that the model of locally sensitive community development, synthesized from Rothman and Jeffries, will surely need to be examined further. The investigation of diverse settings of community practice will enable a clearer understanding of the situations where the interconnection and interplay between the three models cited above are best selected.

\section{References}

Abdullah et.al, M. Amin. Implementasi Pendekatan IntegratifInterkonektif dalam Kajian Pendidikan Islam. Yogyakarta: Program Pascasarjana UIN Yogyakarta, 2014.

Abdullah, M. Amin. “Epistemologi Ilmu Profetik: Apa yang Terlupakan dari Ilmu-ilmu 'Sekuler'?" Paper presented at the Sarasehan Ilmu Profetik II, Ruang Sidang A Lt. 5 school of Post Graduate studies, UGM, July 28, 2011.

- - - . "Interpreting the Quran Responding to the Challenges of the Modern World: Moslem Societies at Crossroads." Paper presented at the Symposium on Social, Ethical, and Policy 
Implications of Interpretations of Islam's Foundational Text: The Quran, New York University's Casa Italiana, November 28, 2010.

- - . "Religion Science and Culture an Integrated, Interconnected Paradigm of Science." Al-Jami'ah: Journal of Islamic Studies 52, no. 1 (2014): 175-203.

Adamson, P. Interpreting Avicienna: Critical Essays. Cambridge: Cambridge University Press, 2013.

Aertsen, J. A. "Avicenna's Doctrine of the Primary Notions and Its Impact on Medieval Philosophy." In Islamic Thought in the Middle Ages: Studies in Text, Transmission and Translation, in Honour of Hans Daiber, edited by A. Akasoy and W. Raven. Leiden, Boston: Brill, 2008.

Ahmad, Nur. "Shedding New Lights on Javanese Mysticism:

Pegon Manuscripts in the Javanese World." Ulumuna 23, no. 2 (2019): 221-241. Accessed June 10, 2020. https://ulumuna.or.id/ index.php/ujis/article/view/370.

Al-Kindi, Ya'qub ibn Ishaq. On First Philosophy. Translated by A. L.

Ivry. Albany: State University of New York Press, 1974.

- - - "On First Philosophy." Stanford University. Last modified 1974. Accessed April 21, 2013. http://plato. stanford.edu/entries/al-kindi/.

Alsubaie, Merfat Ayesh. "Journal of Education and Practice." Journal of Education and Practice 6, no. 33 (2005). www.iiste.org. Arab Republic of Egypt, National Commission for UNESCO. Islamic and Arab Contribution to the European Renaissance. Cairo, Egypt: Associated Institution for the Study and Presentation of Arab Cultural Values, General Egyptian Book Organization, 1977.

Avicenna (Ibn Sīnā). “Ibn Sīnā.” Al-Najah. Cairo, Egypt, 1923.

- - . "Ibn Sina's Metaphysics." Stanford Encylopedia of Philosophy. Standford, n.d. Accessed December 20, 2019. http://plato.stanford.edu/entries/ibn-sina-metaphysics/.

Barker, L.R. The Social Work Dictionary. Washington DC: NASW Press, 2003.

Bimbo, Chusnul Chotimah. "Islam Today in Modern West: Fazlur Rahman's and Tariq Ramadan's Views on Jihad." Ulumuna 23, 
no. 1 (June 28, 2019): 71-89. Accessed June 10, 2020. https://ulumuna.or.id/index.php/ujis/article/view/289. BPS.IPM. "Indeks Pembangunan Manusia." Badan Pusat Statistik. Accessed May 7, 2019. https://www.bps.go.id/subject/ 26/indeks-pe-pembangunan-manusia.html.

Bulliet, Richard W. The Case for Islamo-Christian Civilization. New York: Columbia University Press, 2004.

Bullis, Ronald K. Spirituality in Social Work Practice. Washington DC: Taylor \& Francis, 2005.

Coates, John H. "Ideology and Education for Social Work Practice." Journal of Progressive Human Services 2, no. 3 (1992): 15-30.

Frassetto, Michael. Christian and Muslims in the Middle Ages From Muhammad to Dante. New York: Lexington Books, 2020.

Freire, Paulo. Education for Critical Consciousness. New York: Seabury, 1973.

Gagne, Robert M., ed. Learning and Individual Differences. New York: Charles E. Merril Books, 1967.

Gray, Mel, John H. Coates, and Michael Yellow Bird. Indigenous Social Work Around the World: Towards Culturally Relevant Education and Practice. Burlington: Ashgate Publishing Company, 2010.

Haskins, Charles Homer. The Rise of Universities. New York: Cornel University Press, 1965.

Kuhn, Thomas. The Structure of Scientific Revolutions. Chicago: University of Chicago Press, 1970.

Lammer, Andreas. The Elements of Avicenna's Physics: Greek Sources and Arabic Innovations. Berlin: Walter de Gruyster GmbH, 2018.

Ragab, Ibrahim A. Authentization of Social Work in Developing Countries. Tanta, Egypt: Integrated Social Services Project Publication, 1982.

- - - "How Community Development Can Take Root in Developing Countries." Journal of Social Development Issues 12, no. 3 (1990): 38-51.

- - - "The Islamic Perspective on Social Work: A Conceptual Framework." Journal International Social Work 59, no. 3 (2016): 325-342. 
Reamer, Frederic G. The Philosophical Foundations of Social Work.

New York: Columbia University Press, 1993.

Robbin, P., Pranab Chatterjee, and Edward R. Canda. "Ideology,

Scientific Theory, and Social Work Practice." Journal Families in Society 80, no. 4 (384 374AD): 1999.

Saparudin, Saparudin. "Salafism, State Recognition and Local

Tension: New Trends in Islamic Education in Lombok." Ulumuna 21, no. 1 (June 30, 2017): 81-107. Accessed June 10, 2020. https://ulumuna.or.id/index.php/ujis/article/view/68.

Soeharto, Edi. Pembangunan Sosial dan Pengembangan Masyarakat, Spektrum Pemikiran. Bandung: LSP-STKS, 1997.

Tan, Ngoh Tiong, and Ellis Enval. "Social Work: Challenges in the New Millenium." In Social Work around the World, edited by Ngoh Tiong Tan and Ellis Enval. Zurich: IFSW Press, 2000.

Weil, Mary O., and Dorothy N. Gamble. Community Practice Models in Encyclopedia of Social Work. Washington: NASW Press, 1995. 